\title{
SOME ASPECTS OF THE GROWTH FEATURES AND CONDITION FACTOR OF ARIUS GIGAS (BOULENGER, 1911) FROM OBUAMA CREEK (RIVERS STATE, NIGERIA)
}

\author{
Olaniyi Alaba OLOPADE *, Henry Eyina DIENYE * and Esther Ifeyinwa NWOSU * \\ * University of Port Harcourt, Faculty of Agriculture, Department of Fisheries, Street Choba, East-West \\ Road, PMB 5323, Port Harcourt, Rivers State, Nigeria, NG-500272, olaniyi.olopade@uniport.edu.ng, \\ ORCID: 0000-0002-9550-2956; henry.dienye@uniport.edu.ng, ORCID: 0000-0001-6254-9179; \\ ifeyinwa610@gmail.com
}

DOI: 10.2478/trser-2021-0015

KEYWORDS: length-frequency distributions, length-weight relationship, lengthlength relationship, Giant sea catfish.

\section{ABSTRACT}

Length-frequency distributions, length-weight relationships, length-length relationships and condition factors (Fulton's $\mathrm{K}_{\mathrm{F}}$, allometric $\mathrm{K}_{\mathrm{A}}$, and relative $\mathrm{K}_{\mathrm{R}}$ ) of Arius gigas in the Obuama Creek in Rivers State, Nigeria were investigated. 217 samples were collected from artisanal fishermen fishing on the Obuama Creek from March to September 2019. The parameter b of the length-weight relationship was 2.52 indicating negative allometric growth. The KF ranged from 0.51 to 2.03 with a mean value of $0.85 \pm 0$ while the overall low values of $\mathrm{K}_{\mathrm{R}}$ and $\mathrm{K}_{\mathrm{A}}$ in this study are generally a characteristic of fish in poor health. This study provides basic information on some of the biological features of A. gigas which should be useful for facilitating management strategies and regulations of the stocks.

RÉSUMÉ: Quelques aspects des caractéristiques de croissance et du facteur de condition d'Arius gigas (Boulenger, 1911) d'Obuama Creek (État de la Rivière, Nigéria).

Les distributions de fréquence de longueur, les relations longueur-poids, les relations longueur-longueur et les facteurs de condition (KF de Fulton, KA allométrique et relatif, KR) d'Arius gigas dans le ruisseau Obuama dans l'État de la Rivère, au Nigeria, ont été étudiés. De mars à septembre 2019, 217 échantillons ont été prélevés avec l'aide des pêcheurs artisanaux qui pêchent dans le ruisseau Obuama. Le paramètre b de la relation longueurpoids était de 2,52 indiquant une croissance allométrique négative. Le KF variait de 0,51 à 2,03 avec une valeur moyenne de 0,85 \pm 0 , tandis que les valeurs globales et faibles de KR et de KA dans cette étude sont généralement caractéristiques des poissons en mauvaise santé. Cette étude fournit des renseignements de base sur certaines des caractéristiques biologiques de l'A. gigas qui devraient être utiles pour faciliter les stratégies de gestion et la réglementation des stocks.

REZUMAT: Unele aspecte ale caracteristicilor de dezvoltare și indicele ponderal la Arius gigas (Boulenger, 1911) din Pârâul Obuama (Statul Râurilor, Nigeria).

Distribuțiile lungime-frecvență, relațiile lungime-greutate, relațiile lungime-lungime și factorii de condiție $\left(\mathrm{K}_{\mathrm{F}}\right.$ al lui Fulton, $\mathrm{K}_{\mathrm{A}}$ alometric și relativ $\mathrm{K}_{\mathrm{R}}$ ) ai lui Arius gigas în Pârâul Obuama din Statul Râurilor, Nigeria au fost investigați. 217 probe au fost colectate de la pescari artizanali care își desfăşoară activitatea în Pârâul Obuama în martie-septembrie 2019. Parametrul $b$ al relației lungime-greutate a fost de 2.52 indicând o creștere alometrică negativă. $\mathrm{K}_{\mathrm{F}}$ a variat de la 0.51 la 2.03, cu o valoare medie de $0.85 \pm 0$, iar valorile globale scăzute ale $\mathrm{K}_{\mathrm{R}}$ și $\mathrm{K}_{\mathrm{A}}$ din acest studiu sunt, în general, caracteristice peștilor cu o sănătate precară. Acest studiu oferă informații de bază cu privire la unele dintre caracteristicile biologice ale A. gigas, care trebuie să fie utile pentru facilitarea strategiilor de gestionare și reglementare a stocurilor. 


\section{INTRODUCTION}

The majority of Ariidae fish, which are known as marine catfish, inhabit shallow coastal areas and estuaries in tropical and temperate regions. A restricted number of species is either entirely confined to marine waters where they can be found at depths of $150 \mathrm{~m}$ or to freshwaters in the upper tributaries of rivers $500 \mathrm{~km}$ away from their river-mouths. (Marceniuk and Menzes, 2007) This family has 30 genera and 143 species; the genus Arius has 27 species (Froese and Pauly, 2011). Out of the four species recorded in the Gulf of Guinea, three species are found in the Nigerian freshwaters, these are Arius gigas, Arius lutiscutatus, and Arius heudeloti (Schneider, 1990; Adesulu and Sydenham, 2007).

The giant sea catfish (Arius gigas) is of commercial significance as a food fish and one of the dominant species in the Nigerian Industrial coastal fisheries; however, it's population has declined due to overfishing and possibly chemical pollution from the outcome of these factors, the IUCN red list currently lists the species as Data Deficient (IUCN, 2019). According to the National Bureau of Statistics (2017), fish production by species in Nigerian waters from 2010 to 2015 showed a steady increase in the sea catfish from 2010 (17,236 tons) to 2014 (23,854 tons) and then declined sharply in 2015 to 17,444 tons.

The studies on growth are components of fish stocks management and are used to characterize the state of fish populations. For example, relations between total and standard lengths of fish are important in management for comparative growth studies (Sandoval-Huerta et al., 2014). Information generated from length-weight relations can also be used to assess fish conditions and fish growth patterns, whether isometric or allometric (Pope and Kruse, 2001; Hashim et al., 2017), based on the assumption that heavier fish of a given length are in better condition (Pope and Kruse, 2001; Sandoval-Huerta et al., 2014; Hashim et al., 2017).

Information on the length-weight relationship and condition factor of A. gigas inhabiting the Nigerian water is very scarce and incomplete (IUCN, 2019). Thus, the goal of this study was to assess the length-frequency distributions (LFDs), length-weight relationships (LWRs), length-length relationships (LLRs), and condition factors (allometric, $\mathrm{K}_{\mathrm{A}}$, Fulton's, $\mathrm{K}_{\mathrm{F}}$ and relative, $\mathrm{K}_{\mathrm{R}}$ ) of Arius gigas from the Obuama Creek, Rivers State, Nigeria, so as to provide background information for it's conservation and better management.

\section{MATERIAL AND METHODS}

The study was conducted in Obuama Creek (Fig. 1) a tributary of the Sombrero River, in Rivers State, Nigeria. A freshwater system whose waters originate from outside or wholly within the lowlands of the coast and which experiences tidal effects as manifested in many species of marine fish. Rivers State features a tropical monsoon climate with lengthy and heavy rainy seasons and very short dry seasons. The dry season is between November and March and the wet season is from April to November. In the wet season, annual rainfall is between $49.5 \mathrm{~mm}$ in January and $580 \mathrm{~mm}$ in July and is usually interrupted by a short dry spell in August. The average temperature ranged from $27.1^{\circ} \mathrm{C}$ to $31.1^{\circ} \mathrm{C}$.

Monthly fish samples were collected at random (once a month) from the local fishermen using beach seine nets of various mesh sizes (stretched) ranging between two and $19 \mathrm{~cm}$ from March to September 2019. Specimens were taken from two major landing sites along the creek. Station 1 (Mission Poku) is situated between 04 ${ }^{\circ} 48.004^{\prime}$ North latitude and $006^{\circ} 46.565^{\prime}$ East longitude, while station 2 (Erimia Poku) is situated between 04 $48.033^{\prime}$ North latitudes and $006^{\circ} 46.523^{\prime}$ East longitude (Fig. 1). These two sites are considered representative sampling sites due to the routine landing of $A$. gigas caught by beach seine. A total of 109 and 108 fish samples were recorded in station 1 and station 2, respectively. 


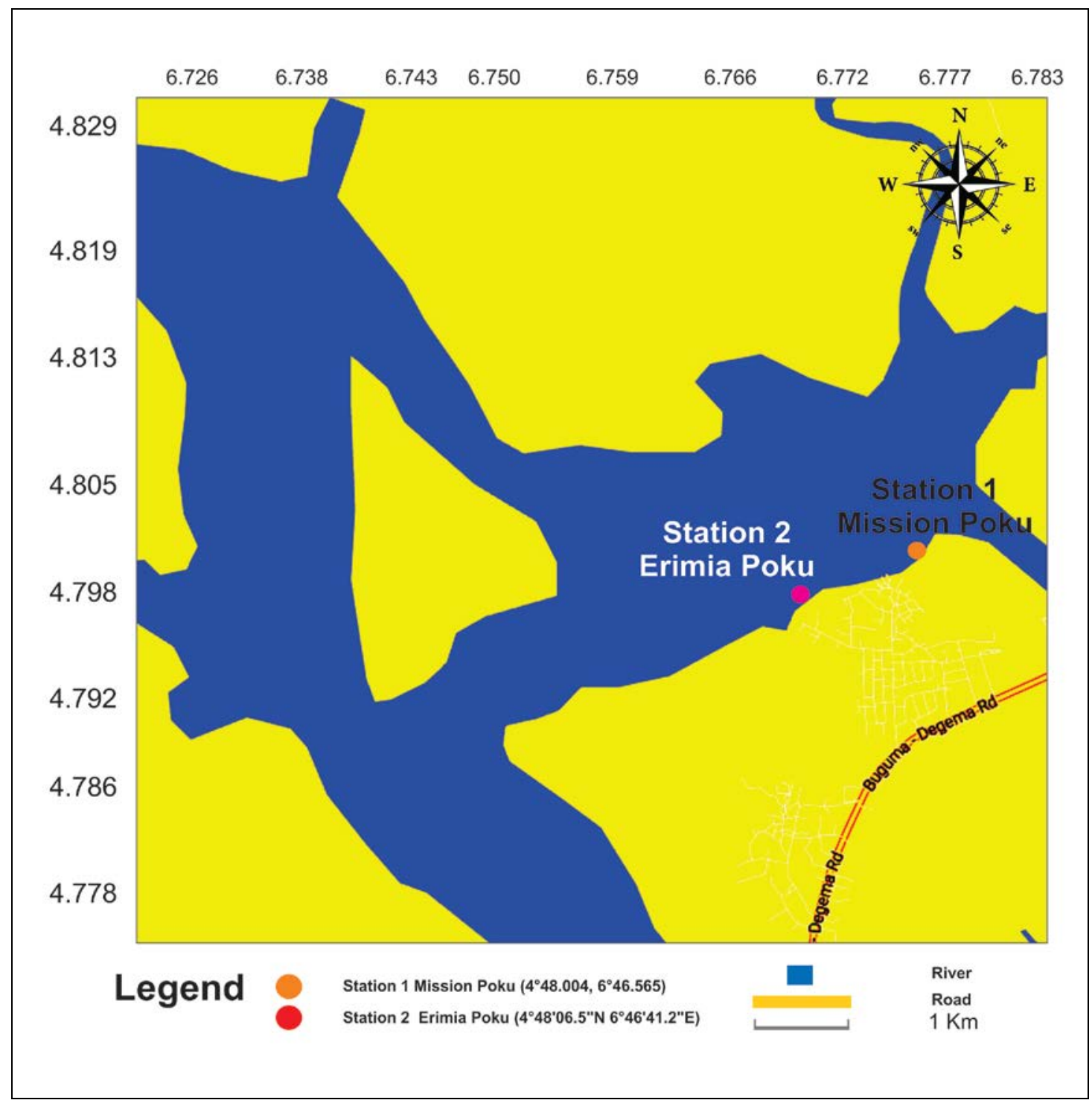

Figure 1: Map of the study area showing the sampling stations on Obuama Creek, Nigeria.

Fresh samples (dead fish) were immediately chilled in ice on site and fixed with $10 \%$ alcohol upon arrival in the Fisheries Laboratory f University of Port Harcourt, Nigeria for proper identification using the keys constructed by Schneider (1990) and Adesulu and Sydenham (2007). After cleaning and washing the specimens, total length (TL), fork length (FL) and standard length (SL) were recorded to the nearest $0.1 \mathrm{~cm}$, and weight (W) was measured with a precision balance (0.01 g).

The length-weight relationships were calculated using the equation $\mathrm{W}=\mathrm{aL}^{\mathrm{b}}$, where $\mathrm{W}$ : body weight (g), L: fish length (TL, $\mathrm{cm}), a$ : regression constant and $b$ : regression coefficient (Le Cren, 1951). The length-length relationships were estimated by the simple linear regression: $\mathrm{Y}=\mathrm{a}+\mathrm{bX}$, where $\mathrm{Y}$ : various body lengths, $\mathrm{X}$ : total length, a: proportionality constant, and b: regression coefficient (Zar, 1996). 
The condition factor $\left(\mathrm{K}_{\mathrm{F}}\right)$ was calculated according to the formula by Fulton (Froese, 2006) as follow: $K_{F}=100 \cdot \mathrm{W} / \mathrm{L}^{3}$, where $\mathrm{W}$ : body weight (g) and L: fish length (TL, $\left.\mathrm{cm}\right)$. The relative condition factor $\left(K_{R}\right)$ for each individual was calculated using the formula by Le Cren (1951): $K_{R}=W /\left(a \cdot L^{b}\right)$, where $W=$ body weight, $L=$ total length, $a$ and $b=L W R$ parameters. The allometric condition factor $\left(\mathrm{K}_{\mathrm{A}}\right)$ was calculated using the formula by Tesch (1968): $\mathrm{K}_{\mathrm{A}}=$ $\mathrm{W} / \mathrm{L}^{\mathrm{b}}$, where $\mathrm{W}=$ body weight and $\mathrm{L}=$ total length and $\mathrm{b}=\mathrm{LWR}$ parameter. The condition factors from the two stations were quantified using t-test.

\section{RESULTS AND DISSCUSION}

The total length ranged from 17 to $39 \mathrm{~cm}$ with a mean value of $26.91 \pm 4.57 \mathrm{~cm}$ and the body weight ranged between 40 and $556 \mathrm{~g}$ with a mean value of $174.25 \pm 90.62 \mathrm{~g}$. The mean values for fork length, standard length and weight of liver weight were $21.40 \pm 4.00$ $\mathrm{cm}, 19.41 \pm 3.80 \mathrm{~cm}$, and $1.96 \pm 1.20 \mathrm{~g}$ respectively. The size of A. gigas in the present study $(17$ to $39 \mathrm{~cm}$ ) was similar to the findings of Abohweyere (2011) who reported that the total length of $A$. gigas ranged from 15-42 cm in Sombreiro River and Creek. However, the size of the species in the present study was lower than in Taylor (1986) who reported a maximum length of $165 \mathrm{~cm}$. This may be related to differences among fishing gear used, and too different of ecological condition of these habitats.

Descriptive values of the length $(\mathrm{cm})$ and weight $(\mathrm{g})$ measurements (TL, FL, SL, W, and $\mathrm{LW}$ ) are presented in table 1. The TL-frequency distribution showed that the maximum population stands on $25 \mathrm{~cm}$ TL size group and dominant length groups were 25 to $29 \mathrm{~cm}$ (Fig. 2). Length-frequency distributions provide a vision to help understand when the fishing pressure starts and ends (Khan and Khan, 2014). In this study, the variation in fish size (length-frequency) indicated that the fish population ranged from immature specimens to fully matured ones with the majority of fish captured by the fishermen in the category of immature or small individuals. This means that the Obuama Creek could be characterized as nursery ground. This is in agreement with Little et al. (1988), who noted that creeks serve as a nursery ground, in which fingerlings are developed. Nevertheless, their large-scale exploitation has resulted in mass destruction of the stock. Heavy fishing produces a population of mainly young small individuals, since the fish are caught as they reach a catchable size and before spawning, so that reproduction capacity of the stock is seriously impaired and where adult survival is lower, the fish begin reproduction at an earlier age and invest a greater proportion of their energy budget into reproduction (Molles, 2010). Therefore, there is a need for regulations requiring a minimum legal size of the fish caught as a conservation measure for $A$. gigas. The minimum mesh size used by the fishermen ranged from two $\mathrm{cm}$ and the maximum size was $19 \mathrm{~cm}$ in the study area. By increasing the minimum mesh size to from two to $7.5 \mathrm{~cm}$, it will reduce juvenile fish being caught and allow the fish mature and reproduce before they are captured. The mesh size $(7.5 \mathrm{~cm})$ was recommended as the standard as minimum mesh size for all inland water bodies in Nigeria. However, in the absence of effective regulations, all native communities in Nigeria have customary laws on water rights. For example, community regulations stipulate who should fish where, when, and with what fishing gear in a river. Other measures include closure of areas, of seasons, ban on taking small fish, and provisions allowing a portion of catch to escape. So, devolution of the resources and allocation decisions to the local fishers will often be the most effective way of resolving uncertainties and improving management (Bailey, 1982). It would be far easier, more effective and less costly. However, in the last few decades, fishing communities in Nigeria have been fragmented as a result of civil unrest and have found it difficult to survive and operate as unit as a result of continuous conflicts in rural areas. Integrating and mobilizing fishermen to manage the fish is the only solution. 
Table 1: Descriptive statistics on the length $(\mathrm{cm})$ and weight $(\mathrm{g})$ measurements of the Arius gigas in the Obuama Creek, Nigeria; n, sample size; TL, total length; SL, standard length; CL, confidence limit for mean values.

\begin{tabular}{|l|l|l|l|l|l|}
\hline \multicolumn{1}{|c|}{ Measurement } & \multicolumn{1}{c|}{ N } & \multicolumn{1}{c|}{ Min } & \multicolumn{1}{c|}{ Max } & \multicolumn{1}{c|}{ Mean + SD } & \multicolumn{1}{c|}{ CL95\% } \\
\hline Body weight $(\mathrm{g})$ & 217 & 40 & 556 & $174.25 \pm 90.62$ & $162.13-186.38$ \\
\hline Total Length $(\mathrm{cm})$ & 217 & 17 & 39 & $26.91 \pm 4.57$ & $26.30-27.52$ \\
\hline Fork Length $(\mathrm{cm})$ & 217 & 13 & 33 & $21.40 \pm 4.00$ & $20.87-21.94$ \\
\hline Standard Length (cm) & 217 & 12 & 30.2 & $19.41 \pm 3.80$ & $18.90-19.92$ \\
\hline Weight of liver (g) & 217 & 0.34 & 6.4 & $1.96 \pm 1.20$ & $1.80-2.12$ \\
\hline
\end{tabular}

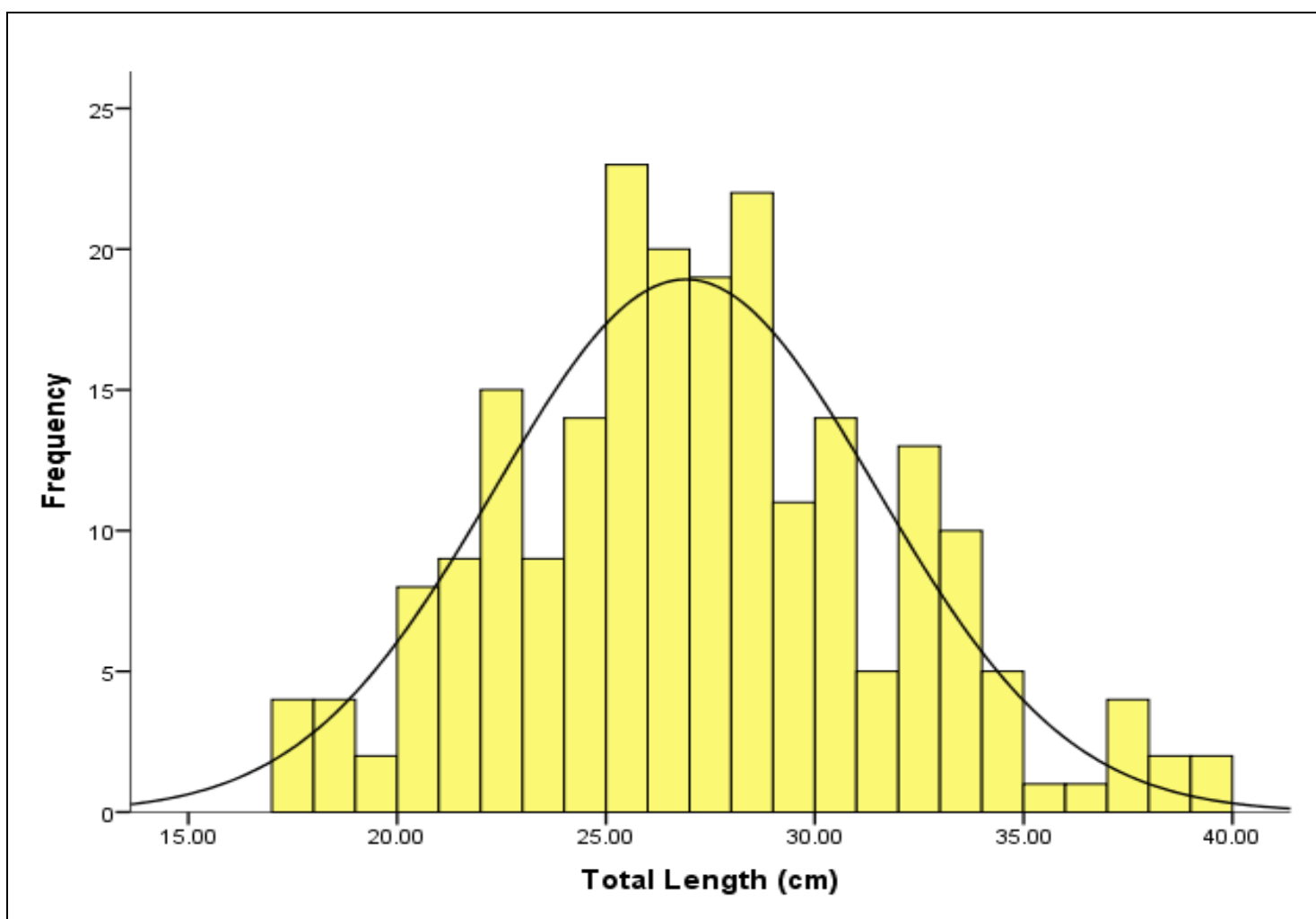

Figure 2: Total length distribution frequency of Arius gigas in the Obuama Creek, Nigeria.

The regression parameters ( $a$ and $b$ ) and their 95\% CL in the LWRs, co-efficient of determination $\left(\mathrm{r}^{2}\right)$ and growth type of A. gigas are shown in table 2 and figure 3 . The exponential value of length-weight relationships ' $b$ ' was 2.52 for the TL vs. $\mathrm{W}, 2.34$ for the FL vs W and 2.22 for SL vs. W (Tab. 2) all which indicated negative allometric growth. The $\mathrm{b}$ value in this study falls between two and four and are close to three that are usually obtained for fishes (Tesch, 1968). By negative allometry (b $<3$ ), the fish is said to be "lighter for its length" as it grows (Froese, 2006). The b parameter of the length-weight relations of fishes is affected by a number of factors, including environmental conditions (such as temperature and salinity), sex, gonad maturity, health, season, habitat, nutrition, area, degree of stomach fullness, differences in the length range of the caught specimen, and the fishing gear used (Tesch, 1971; Froese 2006). 
Table 2: Descriptive statistics and estimated parameters of the length-weight relationships (BW $=\mathrm{a} \times \mathrm{Lb}$ ) with $95 \%$ confidence limits and $-\mathrm{A}$ negative allometric growth types of Arius gigas in the Obuama Creek, Nigeria; TL, total length; FL, fork length, $\mathrm{W}$, body weight; $\mathrm{K}_{\mathrm{A}}$, allometric.

\begin{tabular}{|c|c|c|c|c|c|}
\hline Equation & $\mathrm{a}$ & $\mathrm{b}$ & CL95\% of $a$ & CL95\% of $b$ & $\mathrm{r}^{2}$ \\
\hline $\mathrm{BW}=\mathrm{a} \times \mathrm{TL}^{\mathrm{b}}$ & -3.21 & 2.52 & $-6.98--0.05$ & $1.58-3.64$ & 0.79 \\
\hline $\mathrm{BW}=\mathrm{a} \times \mathrm{FL}^{\mathrm{b}}$ & -2.10 & 2.34 & $-2.99--1.8433$ & $2.33-2.57$ & 0.80 \\
\hline $\mathrm{BW}=\mathrm{a} \times \mathrm{SL}^{\mathrm{b}}$ & -1.50 & 2.22 & $-2.67--0.79$ & $1.99-2.62$ & 0.79 \\
\hline
\end{tabular}

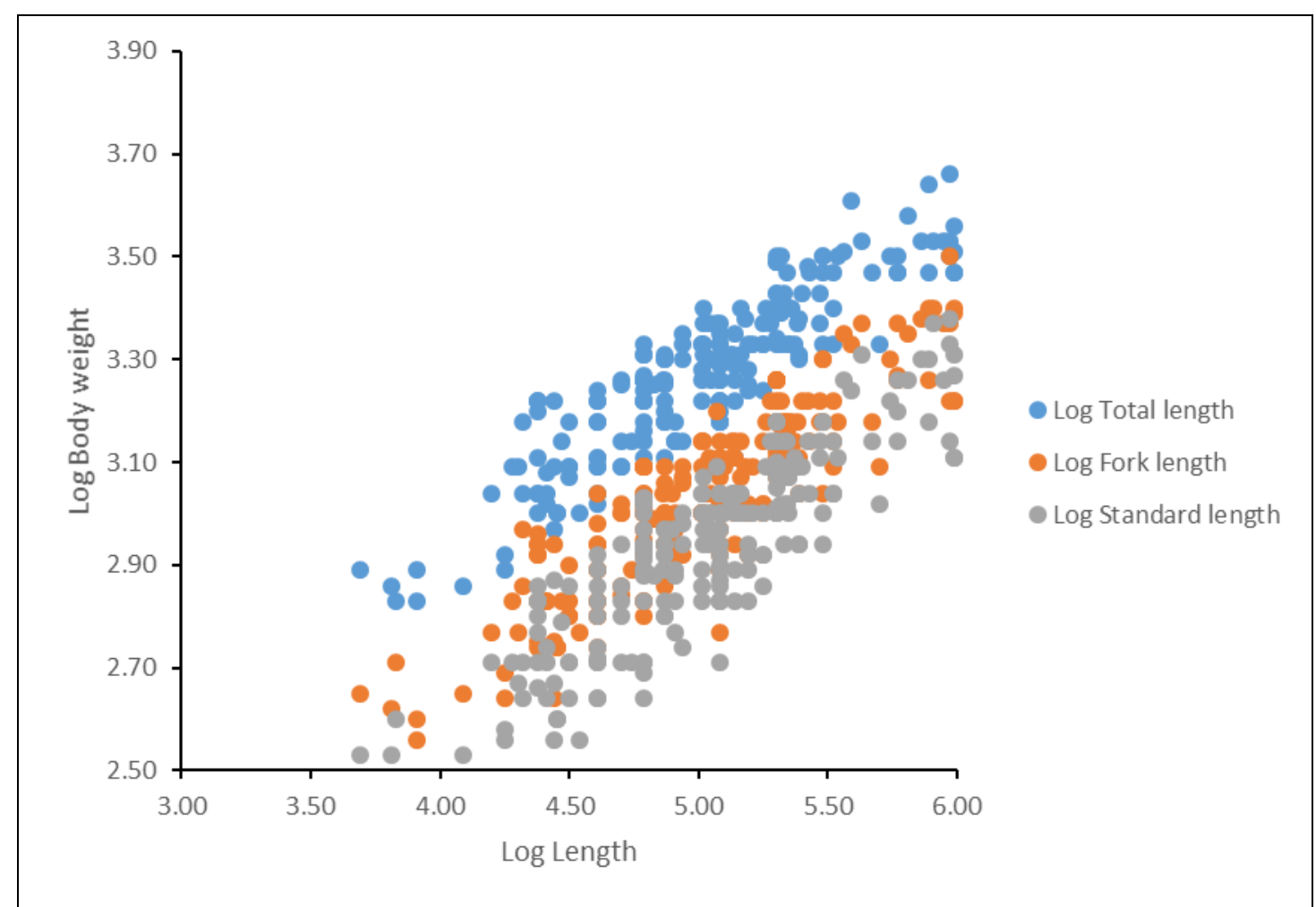

Figure 3: Relationship between the body weight with the total length, fork length, and standard length of Arius gigas in the Obuama Creek, Nigeria.

Furthermore, results of the length-length relationships (SL vs. TL, TL vs FL, and SL vs FL) of A. gigas are presented in table 3 with the regression parameters (a and b) of the LLRs and, co-efficient of determinations $\left(\mathrm{r}^{2}\right)$. The calculated $b$ value was 1.05 for SL vs. TL with the $r^{2}$ value of 0.86 and SL vs FL the $b$ value was 1.02 and $r^{2}$ value was 0.95 while TL vs FL, the $b$ value was 0.87 and $r^{2}$ was 0.89 . LLR is important in fisheries management for comparative growth studies (Moutopoulos and Stergiou, 2002). In this study, the b value of length-length relationships for SL vs. TL, TL vs FL and SL vs FL were 1.05, 1.02 and 0.87 respectively indicating allometric growth $A$. gigas in the Obuama Creek. The results were lower than the minimum and maximum $b$ values of 1.2 and 1.3 respectively reported by Fishbase (2019). The corresponding significant correlation coefficients $\left(\mathrm{r}^{2}\right)$ indicating a length-weight relationships (in log scale) are strongly linear in all the cases. 
Table 3: Descriptive statistics and estimated parameters on the length-length relationships of Arius gigas in the Obuama Creek, Nigeria; TL, total length; FL fork length, SL, standard length; $a$, intercept; $b$, slope ; $\mathrm{r}^{2}$, coefficient of determination.

\begin{tabular}{|c|c|c|c|}
\hline Equation & $\mathrm{a}$ & $\mathrm{b}$ & $\mathrm{r}^{2}$ \\
\hline $\mathrm{SL}=\mathrm{a}+\mathrm{bTL}$ & -0.50 & 1.05 & 0.86 \\
\hline $\mathrm{SL}=\mathrm{a}+\mathrm{bFL}$ & -0.16 & 1.02 & 0.95 \\
\hline $\mathrm{TL}=\mathrm{a}+\mathrm{bFL}$ & 0.62 & 0.87 & 0.89 \\
\hline
\end{tabular}

The condition factor $K_{F}$ ranged from 0.51 to 2.03 with a mean value of $0.85( \pm 0.22)$ close to the standard threshold of one, indicating that the species were in good condition. Carlander (1950) identified $K_{F}$ as a sensitive measure of changes and differences in body form. According to Ricker (1975) condition factor below 0.7 is considered to be low, and above 0.9 is high, the larger the factor the better the condition. This study postulates that the $\mathrm{K}_{\mathrm{F}}$ is the best biometric index for assessing the well-being of this species in the study area with values ranging from 0.51 to 2.03 and a mean value of $0.85 \pm 0.22$. Koivogui et al. (2020) reported lower values of $0.40 \pm 0.04$ to $0.68 \pm 0.05$ and $0.33 \pm 0.04$ to $0.50 \pm 0.06$ for male and female $A$. gigas respectively from the bays of Tabounsou and Sangareah in Republic of Guinea. The condition factor in the lifetime of fish may vary with change depending on various factors such as climatic condition, locations, time, and stages of development (Blackweel et al., 2000). Due to differences in environmental conditions, between systems different fish populations display different levels of condition according to exploitation pressure such as quality and type of fishing gears, level of fishing efforts, food availability, or catchment characteristics (Boys et al., 2012).

Monthly variations of $\mathrm{K}_{\mathrm{F}}$ showed that the lowest value (0.73) was recorded in September and the highest value (2.03) in June (Fig. 4). The monthly variations in condition factors could be attributed to various reasons such as changes in environmental factors with time (i.e. water quality), availability of natural food supply, physiological condition (i.e. accumulation of fat and gonads development) (Jennings et al., 2001) and stage of maturity (Khallaf et al., 2003). The higher condition recorded in June could be attributed to good water quality and an abundance of food in the study area due to the highest rainfall in the month. The condition factor is a quantitative indicator of individual wellbeing reflecting recent food availability conditions (Le Cren, 1951). According to several researchers, many tropical fish were reported to breed at the beginning of the rainy season due to the large varieties of food items (Marsh et al., 1986).

Monthly variations of $K_{F}$ showed that the lowest value (0.73) was recorded in September and the highest value (2.03) in June (Tab. 4). In this study, $\mathrm{K}_{\mathrm{R}}$ was studied in order to evaluate the health and productivity of A. gigas in the Obuama Creek. According to Le Cren (1951) the value of $K_{R}$ higher than one indicates good health and less than one indicates relatively poor condition of the fish. The mean value for $\mathrm{K}_{\mathrm{F}}$ as shown in table 5 below in station 1 was $0.83 \pm 0.02$, while that of station 2 was $0.90 \pm 0.03$. The t test indicates that there was no significant relationship between the two stations $(\mathrm{t}=-2.32=\mathrm{P}<$ 0.16) (Tab. 5). The overall, low values of $K_{R}$ and $K_{A}$ in this study are generally characteristic of fish in poor health. However, low values of $K_{R}$ and $K_{A}$ could be attributed to the fact that the morphometric condition indices may have a limited sensitivity, and provide a rapid, non-invasive measurement of the physiological status of the fish (Brown and Murphy 1991; Neumann and Murphy, 1991). 


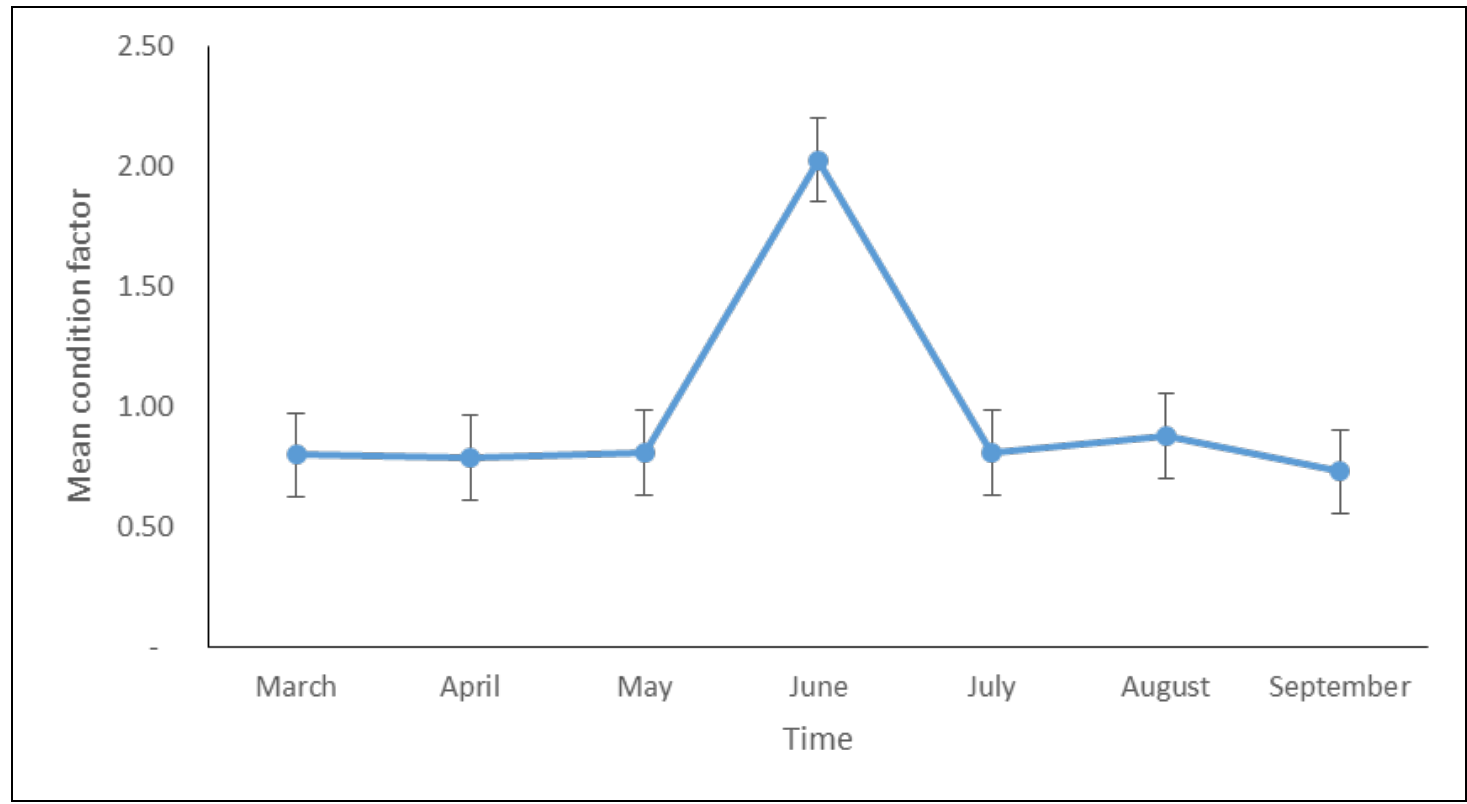

Figure 4: Monthly fluctuation of Fulton's condition factor of Arius gigas in the Obuama Creek, Nigeria.

Table 4: Descriptive statistics and condition factors measurements and their 95\% confidence limits of the Arius gigas in the Obuama Creek, Nigeria; allometric condition factor; $\mathrm{K}_{\mathrm{A}} ; \mathrm{K}_{\mathrm{F}}$; Fulton's condition factor; $\mathrm{K}_{\mathrm{R}}$, relative condition factor values; CL, confidence limit; $\mathrm{P}$, shows the level of significance.

\begin{tabular}{|c|c|c|c|c|c|}
\hline Condition factors & $\mathrm{N}$ & Min & Max & Mean \pm SD & CL $_{95 \%}$ \\
\hline $\mathrm{K}_{\mathrm{F}}$ & 217 & 0.51 & 2.03 & $0.85 \pm 0.22$ & $0.82-0.88$ \\
\hline $\mathrm{K}_{\mathrm{R}}$ & 217 & 0.60 & 1.13 & $0.61 \pm 0.11$ & $0.55-0.61$ \\
\hline $\mathrm{K}_{\mathrm{A}}$ & 217 & 0.52 & 0.71 & $0.54 \pm 0.31$ & $0.04-0.54$ \\
\hline
\end{tabular}

Table 5: Comparisons between conditions factors of Arius gigas in the two stations in the Obuama Creek, Nigeria; allometric condition factor; $\mathrm{K}_{\mathrm{A}} \mathrm{K}_{\mathrm{F}}$; Fulton's condition factor; $\mathrm{K}_{\mathrm{R}}$, Relative condition factor.

\begin{tabular}{|c|c|c|c|c|c|}
\hline & Station 1 & Station 2 & t-value & p-value & Decision \\
\hline $\mathrm{K}_{\mathrm{F}}$ & $0.83 \pm 0.02$ & $0.90 \pm 0.03$ & -2.32 & 0.16 & $\mathrm{NS}$ \\
\hline $\mathrm{K}_{\mathrm{R}}$ & $0.61 \pm 0.03$ & $0.70 \pm 0.01$ & -2.22 & 0.18 & $\mathrm{NS}$ \\
\hline $\mathrm{K}_{\mathrm{A}}$ & $0.57 \pm 0.01$ & $0.64 \pm 0.02$ & -2.10 & 0.15 & $\mathrm{NS}$ \\
\hline
\end{tabular}




\section{CONCLUSIONS}

This study provides important data on the length frequency distributions length-weight relationship, length-length relationships, and condition factors of Arius gigas from Obuama Creek which should be useful in facilitating management strategies and regulations for the sustainable conservation of the fish stocks of this species. 


\section{ACKNOWLEDGEMENTS}

We thank the University of Port Harcourt, Faculty of Agriculture, Rivers State, Nigeria for providing access to the equipment and facilities during this study. 


\section{REFERENCES}

1. Abohweyere P. O., 2011 - Fisheries innovative data collection strategy: the case of selfsampling in artisanal fisheries of Bonny, Nigeria, International Journal Biological and Chemical Science, 5, 5, 2014-2021.

2. Adesulu E. A. and Sydenham D. H. J., 2007 - The freshwater and fisheries of Nigeria, Macmillan Nigeria Publishers, Lagos, Nigeria, 397.

3. Bailey C., 1982 - Small-scale fisheries of San Miguel Bay, Philippines: occupational and geographic mobility, ICLARM Technical Reports, 10, 56.

4. Blackweel B. G., Brown M. L. and Willis D.W., 2000 - Relative weight (Wr) status and current use in fisheries assessment and management, Reviews in Fisheries Science, 8, 1-44.

5. Boys C. A., Rowland S. J., Gabor M., Gabor L., Marsh I. B., Hum S. and Callinan R. B., 2012 - Emergence of epizootic ulcerative syndrome in native fish of the Murray-Darling riversystem, Australia: hosts, distribution and possible vectors, PLoS ONE 7, 4, e35568.

6. Brown M. L. and Murphy B. R., 1991 - Standard weight (Ws) development for striped bass, white bass and hybrid striped bass, North American Journal Fisheries Management, 11, 451-467.

7. Carlander K. D., 1950 - Handbook of freshwater fishery biology, William C. Brown Company, Dubuque, Iowa, USA, 281.

8. FishBase, 2019 - Online fish identification sheet, available at http://www.fishbase.org/search.php, (accessed on 10/11/2019).

9. Froese R., 2006 - Cube law, condition factor and weight-length relationships: history, metaanalysis and recommendations, Journal of Applied Ichthyology, 22, 241-253, DOI: 10.1111/j.1439-0426.2006.00805.x.

10. Froese R. and Pauly D., (eds). 2011 - Fishbase 2011, World Wide Web electronic publication, available at: http://www.fishbase. org (accessed on 22 October 2019).

11. Hashim M., Abidin D. A. Z., Das S. K. and Mazlan A. G., 2017 - Length-weight relationship, condition factor and TROPH of Scatophagus argus in Malaysian coastal waters, AACL Bioflux, 10, 2, 297-307.

12. Jennings S., Kaiser M. J. and Reynolds J. D., 2001 - Marine fisheries ecology, Blackwell Science, Oxford, 458.

13. Khallaf E., Galal M. and Athuman M., 2003 - The biology of Oreochromis niloticus in a polluted canal, Journal of Ecotoxicology, 12, 405-416.

14. Khan S. and Khan M. A., 2014 - Importance of age and growth studies in fisheries management, Reviewed Proceedings of National Seminar on NGSV, Next Generation Sciences: Vision 2020 and Beyond, Rohtak, Haryana, India, 194-201.

15. Koivogui P., Konan Y.A., Coulibaly B., Kouamelan E.P. and Koné T., 2020 - Reproductive biology of marine catfish, Arius latiscutatus (Günther, 1864) and Arius gigas (Boulenger, 1911) from the bays of Guinea, Annual Research and Review in Biology, 35, 8, 1-13.

16. IUCN, 2019 - The IUCN Red List of Threatened Species, Version 2019-2.

17. Le Cren D. E., 1951 - The length weight relationship, seasonal cycle, gonad weight and condition in the perch, Perca fluviatilis, Journal of Animal Ecology, 20, 201-219.

18. Little M. C., Ready R. J. and Grove S. J., 1988 - The fish community of Eastern African mangrove system creek, Journal of Fish Biology, 32, 729-749, doi.org/10.1111/j.10958649.1988.tb05413.x

19. Marceniuk A. P. and Menezes N. A., 2007 - Systematics of the family Ariidae (Ostariophysi, Siluriformes), with a redefinition of the genera. Zootaxa, 1416, 1-126.

20. Marsh B. A., Marsh A. C. and Ribbink A. J., 1986 - Reproductive seasonality in a group of rock-frequenting cichlid fishes in Lake Malawi, Journal Zoology, 209, 9-20.

21. Molles M. C. Jr., 2010 - Ecology: concepts and applications (5th ed.), New York, NY: McGraw-Hill. 
22. Moutopoulos D. K. and Stergiou K. I. 2002 - Length-weight and length-length relationships of fish species from Aegean Sea (Greece), Journal of Applied Ichthyology, 18, 3, 200-203, doi.org/10.1046/j.1439-0426.2002.00281.x

23. National Bureau of Statistics (NBS), 2017 - Nigerian's fish production 2010-2015, Data is supplied, verified and validated by the National Bureau of Statistics, Nigeria (NBS), https:// www.nigerianstat.gov.ng/elibrary (accessed on 17 November 2018).

24. Neumann R. M. and Murphy R. B., 1991 - Evaluation of the relative weight (Wr) index for assessment of white and black crap-pie populations, North American Journal of Fisheries Management, 11, 543-555.

25. Pope K. L. and Kruse C. G., 2001 - Assessment of fish condition data, Statistical analyses of freshwater fisheries data American Fisheries Society Publication, 74.

26. Ricker W. E., 1975 - Computation and interpretation of biological statistics of fish populations, Bulletin of the Fisheries Research Board of Canada, 191, 328.

27. Sandoval-Huerta E. R., Madrigal-Guridi X., Escalera-Vázquez L. H., Medina-Nava M. and Domínguez-Domínguez O., 2014 - Estructura de la comunidad de peces en cuatro estuarios del Pacífi co mexicano central, Revista Mexicana de Biodiversidad, 85, 4, 1184-1196, DOI: 10.7550/rmb.42105. (in Spanish)

28. Schneider W., 1990 - FAO species identification sheets for fishery purposes, Field guide to the commercial marine resources of the Gulf of Guinea, Prepared and published with the support of the FAO Regional Office for Africa. Rome, FAO, 268.

29. Taylor W. R., 1986 - Ariidae, in Daget J., Goss, J.-P. and Thys van den Audenaerde D. F. E. (eds), Check-list of the freshwater fishes of Africa, ISNB Bruxelles, MRAC Tervuren, ORSTOM, Paris, 2, 153-159.

30. Tesch F. W., 1968 - Age and growth, in Ricker W. E (ed.), Methods for Assessment of Fish Production in Fresh Waters, Oxford, Blackwell Scientific Publications, 93-123.

31. Tesch F. W., 1971 - Age and growth, in Ricker W. E. (ed.), Methods for assessment of fish production in fresh waters, Oxford: Blackwell Scientific Publications, 99-130.

32. Zar J. H., 1996 - Biostatistical analysis, 3rd edition, Prentice Hall, 662. 